\title{
Fundamental tax reform in the Netherlands
}

\author{
Citation for published version (APA):
}

Cnossen, S., \& Bovenberg, A. L. (2000). Fundamental tax reform in the Netherlands. METEOR, Maastricht University School of Business and Economics. METEOR Research Memorandum No. 024 https://doi.org/10.26481/umamet.2000024

Document status and date:

Published: 01/01/2000

DOI:

10.26481/umamet.2000024

Document Version:

Publisher's PDF, also known as Version of record

\section{Please check the document version of this publication:}

- A submitted manuscript is the version of the article upon submission and before peer-review. There can be important differences between the submitted version and the official published version of record.

People interested in the research are advised to contact the author for the final version of the publication, or visit the DOI to the publisher's website.

- The final author version and the galley proof are versions of the publication after peer review.

- The final published version features the final layout of the paper including the volume, issue and page numbers.

Link to publication

\footnotetext{
General rights rights.

- You may freely distribute the URL identifying the publication in the public portal. please follow below link for the End User Agreement:

www.umlib.nl/taverne-license

Take down policy

If you believe that this document breaches copyright please contact us at:

repository@maastrichtuniversity.nl

providing details and we will investigate your claim.
}

Copyright and moral rights for the publications made accessible in the public portal are retained by the authors and/or other copyright owners and it is a condition of accessing publications that users recognise and abide by the legal requirements associated with these

- Users may download and print one copy of any publication from the public portal for the purpose of private study or research.

- You may not further distribute the material or use it for any profit-making activity or commercial gain

If the publication is distributed under the terms of Article $25 \mathrm{fa}$ of the Dutch Copyright Act, indicated by the "Taverne" license above, 


\title{
FUNDAMENTAL TAX REFORM IN THE NETHERLANDS
}

Sijbren Cnossen and Lans Bovenberg

\begin{abstract}
The Dutch Parliament has passed legislation for a new income tax that abolishes the current tax on personal capital income and substitutes it by a presumptive capital income tax, which is in fact a net wealth tax. This paper contrasts this wealth tax with a conventional realization-based capital gains tax, a retrospective capital gains tax which attempts to charge interest on the deferred tax, and a capital accretion tax which taxes capital gains as they accrue. None of the approaches meets all criteria for a 'good' income tax, i.e., equity, efficiency, and administrative feasibility. We thus conclude that the effective and neutral taxation of capital income can best be ensured through a combination of (a) a capital accretion tax to capture the returns on easy-tovalue financial products, (b) a capital gains tax with interest to tax the returns on hardto-value real estate and small businesses, and (c) a broad presumptive capital income tax, i.e., a net wealth tax, to account for the utility of holding wealth. We favor uniform and moderate proportional tax rates in the context of a dual income tax under which capital income is taxed separately from labor income.
\end{abstract}

Keywords: capital income taxation, capital gains taxation, tax reform, wealth tax

JEL Classification: $\mathrm{H} 2$

Sijbren Cnossen, Economics Faculty, Maastricht Universtiy, P.O. Box 616, 6200 MD, Maastricht, The Netherlands. E-mail: cnossen@few.eur.nl; tel. 31-10-4081485; fax 31-10-4089166.

A. Lans Bovenberg, Economics Faculty, University of Tilburg, P.O. Box 90153, 5000 LE Tilburg, The Netherlands. E-mail: a.l.bovenberg@kub.nl. 


\title{
FUNDAMENTAL TAX REFORM IN THE NETHERLANDS
}

\author{
Sijbren Cnossen ${ }^{*}$ and Lans Bovenberg ${ }^{*}$ *
}

\section{Introduction}

In September 1999, the Dutch Government submitted a bill for a new personal income tax to the Lower House of Parliament. The bill was approved in February 2000 and subsequently passed by the Upper House in May of the same year. ${ }^{1}$ The act, which becomes effective as of January 1, 2001, is part of a broader tax reform package aimed at stimulating employment and protecting the natural environment. Apart from a general cut in the overall tax burden, direct taxes on labor income are reduced in exchange for an increase in indirect taxes on consumption and pollutants. Most of the popular appeal of the tax reform can be attributed to the lowering of the top marginal tax rates on personal income and increased in-work benefits for those earning low labor incomes, reflecting the preferences of the two main coalition partners, i.e. the free-market liberals and the social democrats.

The most radical change in the new personal income tax is the introduction of a presumptive tax on personal capital income. Henceforth, the taxable returns on personally held assets, such as savings deposits, stocks and bonds, and real estate (excluding owner-occupied housing), will be set at a presumptive percentage of $4 \%$ of the value of these assets net of liabilities, regardless of the actual returns. The amount thus computed will be taxed at a rate of $30 \%$. The presumptive capital income tax is thus equivalent to a net wealth tax or a net assets tax levied at a rate of $1.2 \%$ (i.e., $30 \%$ of $4 \%$ ). The presumptive capital income tax replaces the progressive tax on actual personal capital income, i.e., interest, dividends, and rental income (capital gains on personally held assets are currently not taxable in the Netherlands), as well as the existing net wealth tax. ${ }^{2}$

The presumptive capital income tax is unique in the industrialized world. In contrast to the Netherlands, other countries, including most other member states of the European Union and the United States, impose a capital gains tax, separately or in conjunction with a personal income tax on other actual capital income. Interestingly, most of these countries are in the process of strengthening their capital gains taxes. A drawback of conventional realization-based capital gains taxes is that the effective tax rate declines with the holding period of the asset. To repair the attendant deferral effect, the scholarly literature has developed a retrospective capital gains tax which charges interest on the deferred tax at the time of realization. Recently, this literature

\footnotetext{
${ }^{*}$ Erasmus University Rotterdam, Maastricht University, and New York University.

** Tilburg University, Erasmus University Rotterdam, and CEPR.

${ }^{1}$ See Wet inkomstenbelasting 2001, State Gazette, May 11, 2000, nrs 215 and 216. For the initial explanatory memorandum, see Tweede Kamer, 1998-1999, 26727, nr. 2. Additional legislation dealing with transitional and some other issues will be introduced before 2001 .

${ }^{2}$ The existing net wealth tax is levied at a rate of $0.7 \%$ on the value of all assets net of liabilities. Compared to the new presumptive capital income tax, the current net wealth tax features a broader base, which includes owner-occupied housing and the equity capital of proprietorships and closelyheld companies. However, the existing net wealth tax features a more generous basic exemption (90,756 euro per individual) than the new presumptive capital income tax (17,000 euro per individual).
} 
has also drawn attention to the feasibility of a so-called capital accretion tax which, for a long time, has been the normative goal for the taxation of capital income. In addition to current capital income, all personal capital gains would be taxed, regardless of whether these gains have been realized or not.

This paper evaluates the Dutch presumptive capital income tax as well as its principal alternatives. We first provide a brief overview of the Dutch tax reform, which takes a schedular approach to taxing personal income by allocating various income items to a number of so-called boxes (section 2). Subsequently, we characterize the tax reform and review the major ways in which personal capital income, broadly defined, can be taxed (section 3). Against this background, the alternatives are explored in greater detail: the presumptive capital income tax (section 4), a conventional realizationbased capital gains tax (section 5), a retrospective capital gains tax (section 6), and a capital accretion tax (section 7).

All alternatives appear to suffer from particular shortcomings, as summarized in the final section 8. We conclude that an approach that combines elements from all alternatives is the least unattractive option, particularly if the taxes are levied at a moderate, uniform rate on all capital income, separately from the tax on labor income. In our view, the capital income component of this dual income tax should comprise (a) a capital accretion tax to capture the returns on easy-to-value liquid assets, such as financial products, (b) a capital gains tax to tax the returns on hard-to-value illiquid assets, such as real estate and small businesses, and (c) a broad presumptive capital income tax, i.e. a net wealth tax, to account for the utility of holding wealth. At the business level, the tax mix should include the corporation tax (to tax the return on equity) and a withholding tax on interest (coordinated with other countries).

\section{Outline of the tax reform}

For a good understanding of how capital income is taxed under the new act, this section briefly reviews the entire new Dutch income tax. Scheme 1 summarizes the main elements. Under the new personal income tax, taxable personal income is assigned to one of three so-called boxes. As shown in the scheme, box 1 consists mainly of labor income items. These items include the labor income that a selfemployed person (proprietor) earns in his or her business (labeled business profits for tax purposes) and the fictitious wage attributed to the director-shareholder of a closely-held company. ${ }^{3}$

\section{[Scheme 1]}

\footnotetext{
${ }^{3}$ The fictitious wage income of a director-shareholder that is taxable in box 1 is generally deemed to be euro 40,454, but, exceptionally, the wage income can be higher or lower if commensurate with the director's position. This anti-avoidance provision was introduced in 1997 to discourage directorshareholders from relabeling their labor income as company profits. The provision has lost much of its significance following the reduction of the top income tax rate to $52 \%$ and the introduction of relatively low effective tax rates in box 3 (see below), which should stimulate profit distributions.
} 
Also some capital income items are included in box 1. The most important ones are the proceeds of capital that proprietors employ in their own businesses and the income from owner-occupied housing (i.e. presumptive rental income minus mortgage interest). ${ }^{4}$ Also interest, rental income and realized capital gains on assets put at the disposal of closely-held companies by dominant shareholders ${ }^{5}$ are allocated to this box. This anti-avoidance provision prevents these shareholders from shifting their taxable income away from box 1, which is subject to relatively high marginal tax rates, towards box 3, which features lower effective tax rates. The sum of labor and capital income allocated to box 1 is taxed at progressive rates ranging from $32.9 \%$ in the first bracket (comprising mainly social security contributions) to $52 \%$ in the top bracket. The tax thus computed is reduced by a number of tax credits (including substantial in-work benefits), which can be applied only to the income of this box.

Profit distributions of closely-held companies, in which particular shareholders hold a dominant stake, are allocated to box 2. Also included in this box are capital gains realized when a part or the whole of a dominant holding is sold. The nominal personal tax rate on these income items is $25 \%$, but the effective overall tax rate is higher, because these items are subject also to the corporation tax of $35 \%$. Scheme 1 indicates that the labor income of a director-shareholder, if and to the extent this income exceeds his fictitious wage, and the retained profits of a closely-held company are subject to the corporation tax in box 4 . In contrast to box 1, effective tax rates on capital income allocated to box 2 vary depending on the extent to which the realization of capital gains is deferred.

Box 3 includes (the returns on) individually held assets, such as savings deposits, stocks, bonds, and real estate (except owner-occupied housing). The items in this box are subject to the presumptive capital income tax. The statutory rate is $30 \%$ on a presumptive return of $4 \%$. The resulting nominal tax rate of $1.2 \%$ on the value of the taxable assets is thus proportional. Expressed as a percentage of the actual return, however, the tax liability differs between assets depending on the actual return. Specifically, the effective tax rate on the actual return is lower (higher) than $30 \%$ if the actual return is higher (lower) than $4 \%$. If the actual return is $8 \%$, for instance, the effective tax rate (expressed as a percentage of that actual return) amounts to only $15 \%$ rather than the statutory tax rate of $30 \%$ (i.e., the rate at which the presumptive return of $4 \%$ is taxed). Viewed as a tax on actual capital income, the presumptive tax on capital income is thus regressive. The higher the actual return becomes, the lower is the tax expressed as a percentage of that return.

Scheme 1 includes a fourth box - not mentioned in the new income tax act - in which the current profits of corporations (publicly- and closely-held companies) are subject to the corporation tax - an adjunct to the personal income tax - at a statutory rate of $35 \%$. The tax reform does not affect this box; corporate entities are taxed under a separate act. The classical corporate tax system, under which distributed profits are taxed separately at the company level (under the corporation tax) and the shareholder level (under the income tax), is thus maintained. Nevertheless, the reform of the

\footnotetext{
${ }^{4}$ Presumptive rental income from owner-occupied housing is computed as $1.25 \%$ of the value of the property which is well below market rental values. Since nominal interest on mortgages can be deducted in full, the income from owner-occupied housing is typically negative.

5 A shareholder (with or without associated persons) is deemed to be a dominant shareholder for tax purposes if (s)he owns at least $5 \%$ of the shares of a (closely-held) company.
} 
personal capital income tax importantly alters the economic effects of the classical system, as explained below.

A fifth box - also not mentioned in the new act - includes tax exempt capital income. In particular, pension savings can accumulate without attracting capital income tax. Moreover, non-residents are generally not taxed by the Dutch tax authorities on the return of their debt holdings in the Netherlands (the return on equity paid to nonresidents, in contrast, is subject to corporation tax).

\section{Alternative ways of taxing capital income}

\section{a. How should the tax reform be characterized?}

Capital income can be taxed on the basis of either the actual (ex-post) return or the expected (ex-ante) return. An ex-ante tax includes in its base the normal risk-free return to capital (i.e., the return to waiting) and any foreseeable above-normal returns associated with tradable assets. By capitalizing these latter returns in asset values, financial arbitrage in efficient and transparent capital markets ensures that ex-ante returns (adjusted for risk) on various tradable assets are in fact equalized. In addition to the returns included in the base of an ex-ante tax, an ex post tax taxes the additional return originating in investor-specific abilities (which can be viewed as remuneration for the application of human capital) and information advantages. This additional return escapes the ex ante tax, because superior investor insight is associated with the investor instead of the asset and, hence, is not be capitalized in asset values. Another important difference between the two approaches involves the treatment of risk. Only under an ex-post tax does the government consistently share in the risk of the investor.

The presumptive capital income tax (and hence the equivalent net wealth tax) is an ex-ante tax on the expected investment return. A capital gains tax and a capital accretion tax, in contrast, are ex-post taxes. These two ex-post taxes differ, however, with respect to the application of the realization rule. A capital gains tax includes only realized capital gains in its base - usually without interest on the deferred tax, but at the time of realization interest could in principle be charged by a so-called retrospective capital gains tax. A capital accretion tax, in contrast, taxes all accrued gains, including the gains that have not yet been realized.

This taxonomy reveals that various types of capital income are taxed differently under the new Dutch income tax. Capital income is sometimes taxed on an ex-ante basis, sometimes on an ex-post basis, and sometimes not at all. In addition, the rates at which (ex-ante or ex-post) capital income is taxed vary; sometimes the rates are proportional, but in other cases progressive rates apply. Specifically -

- The return on equity, including capital gains, invested in proprietorships and closely-held companies is taxed on an ex-post basis - at progressive rates if accruing in proprietorships and at proportional rates if accruing in closely-held companies. Capital gains are taxed on a realization basis without interest on the deferred tax. 
- The return on equity (shares) invested in publicly-held companies is taxed on an ex-post basis at the company level and on an ex-ante basis at the personal level. At both levels proportional rates apply.

- The return on individually held assets, such as savings deposits, debt claims and real estate is generally taxed on an ex-ante basis at the personal level. This applies also to owner-occupied property - be it that the presumptive return is merely $1.25 \%$ (which is considerably lower than the presumptive return of $4 \%$ in box 3 ) and that the presumptive return is taxed at progressive rates (in box 1) instead of at a proportional rate (in box 3). Exceptionally, the return on debt capital and real estate put at the disposal of closely-held companies by dominant shareholders is taxed on an ex post basis at progressive rates (in box 1).

- The returns on savings held in pension funds and debt claims of non-residents are not taxed. Depending on the difference between the tax rate at which pension contributions are deductible and the tax rate at which pension payouts are taxable, the return on pension savings is in fact subsidized through the tax system. ${ }^{6}$

\section{b. What are the alternatives?}

All types of capital income could be taxed in a uniform way, that is to say, only on an ex-ante basis or only on an ex-post basis - and in the latter case on a realization basis (with or without interest on the deferred tax) or an accretion basis. Under each of these four alternatives, the capital income items in Scheme 1 would have to be reallocated as follows:

\section{- Presumptive capital income tax}

All capital income would be taxed on an ex-ante basis in the same manner as the assets in box 3. Accordingly, capital invested in proprietorships and owner-occupied housing (allocated to box 1 from January 1, 2001 onwards) would have to be transferred to box 3. The same applies to capital invested in closely-held companies, whether directly (in box 2) or indirectly (in box 1). In principle, also pension savings (box 5) could be placed in box 3. The corporation tax (box 4) could be abolished.

\section{- Capital gains tax}

All capital income, current as well as realized capital gains, would be taxed on an expost basis in the same way as the income of assets assigned to box 2. This implies that the assets currently assigned to boxes 1 and 3 would be transferred to box 2 . In principle, the exemption for capital income from pension savings would have to be abolished. The corporation tax could be maintained, but in taxing dividends and capital gains at the level of the individual, the corporation tax attributable to distributed profits should be credited against the personal income tax on the grossedup dividends (imputation system) and a write-up of basis of shares by retained profits net of corporation tax should be permitted when taxing capital gains.

\footnotetext{
${ }^{6}$ The return on pension savings is taxed at the time the pension benefit is paid out. This tax is exactly equal to the advantage of tax deferral on the paid-in contributions if the rates at which benefits are taxed coincide with the rates at which the contributions are deductible. Under these circumstances, therefore, income from pension savings is in fact tax exempt. However, since the rates at which pension benefits are taxed are generally lower than the rates at which contributions can be deducted, pension savings are typically subsidized.
} 
- Retrospective capital gains tax

All capital income would be taxed in the same manner as under a conventional capital gains tax, but, in addition, interest would be charged on the deferred tax as if the gains had been taxed as they accrued.

\section{- Capital accretion tax}

All capital income would be taxed on an ex-post basis and all accrued capital gains would be taxed on the basis of the accretion principle - also at the level of proprietorships and pension funds. For closely- and publicly-held companies, the accretion tax could imply that the corporation tax should be abolished. Alternatively, the corporation tax could serve as a withholding tax at the company level for the capital income and accretion tax at the individual level.

The following sections evaluate these four alternatives on the basis of generally accepted criteria for a 'good' income tax, namely equity (ability-to-pay), neutrality, and enforcement. The ability-to-pay criterion requires a comprehensive definition of income, defined as the sum of consumption and the real accretion of wealth in some period (generally, the calendar year). ${ }^{7}$ Neutrality implies that fundamental economic signals rather than tax considerations should guide the behavior of investors and entrepreneurs. This general principle is violated if the tax to be paid depends on the choice between lending or investing, the form in which a business is conducted, or its financing structure and dividend policy. Enforcement means that opportunities for arbitrage (strategic trading purely for tax advantages) are minimized.

\section{Presumptive capital income tax}

\section{a. Equity considerations}

Taxing capital income on a presumptive basis violates ability-to-pay measured in terms of income. Firstly, under a presumptive capital income tax, the government exempts above normal returns that originate in superior investment insight and information advantages. These additional returns, which are attributable to the application of labor and other investor-specific production factors, escape tax. This is in contrast to above-normal returns due to superior entrepreneurial skills applied in businesses. These returns are taxed at the business level at the progressive personal income tax rates (of up to 52\%) or at the corporation tax rate (of $35 \%$ ).

Secondly, under a presumptive capital income tax, the government does not share in the good and bad luck of investors. This violates the ability-to-pay criterion and may also harm efficiency. In particular, if private risk pooling is inefficient, the government may be better equipped to pool investment risks, for example because of its ability to share risks across generations through public debt policy. By stepping back as insurance agent, the government foregoes the insurance premium, i.e., the tax

\footnotetext{
7 This is generally known as the S-H-S (Schanz-Haig-Simons) concept of income, after the authors who originally introduced the concept, i.e. George Schanz, Robert M. Haig, and Henry C. Simons. See, especially, Simons (1938) and for a modern interpretation Goode (1975). Taking the criteria for a good income tax as our point of departure, we assume that ability to pay should be measured by income largely a value judgment. We realize, however, that wealth and consumption can also be appropriate tax bases for assessing ability-to-pay.
} 
on the risk premium. If the government effectively pools risks, this latter tax is not a burden on the private sector: rather, it is the price that the private sector is willing to pay to the government for pooling macroeconomic risks.

\section{b. Neutrality}

The effects of the new tax regime on economic choices differ from the effects under the old regime. We consider the differential impacts on the financing structure of businesses and the form in which a business is conducted.

\section{Debt versus equity}

The current Dutch income tax regime encourages publicly-held companies to finance their investments through profit retention rather than debt. This is because the corporation tax rate (35\% plus the $0 \%$ tax rate on personal capital gains) is typically lower than the progressive rates (of up to $60 \%$ ) of the personal income tax at which interest accruing to higher income groups (where share- and debt holdings are concentrated) is taxed. Accordingly, profit retention enables shareholders to reduce the tax rate on the return of their investments from the relatively high personal income tax rate to the relatively low corporation tax rate.

The presumptive capital income tax reverses the privileged position of retained profits versus debt. In particular, the relatively high personal income tax rate (of up to $60 \%$ ) on actual nominal interest income is replaced by a relatively low $30 \%$-rate on a presumptive return of only $4 \%$. This wealth tax of $1.2 \%$ on the value of debt holdings applies also to shareholdings. Hence, the current personal income tax on actual capital income, which taxes the return on debt but exempts capital gains (i.e., the return on equity), is replaced by a wealth tax (i.e., the presumptive capital income tax), which taxes not only debt but also equity. The tax discrimination against equity at the corporate level (the normal return on equity is, in contrast to interest, not deductible in ascertaining taxable profits) is therefore no longer mitigated by tax concessions for equity at the personal level (the current personal income tax exempts capital gains but taxes interest). On account of the tax discrimination of equity under the corporation tax, shareholders, under the new regime, benefit from profit distributions, which they can subsequently invest in bonds. Similarly, dominant shareholders in closely-held companies are stimulated to withdraw their equity from the company and replace it by debt or leased real estate. However, a (complicated) anti-avoidance provision in the new act taxes all income on capital put at the disposal of such companies in box 1 (see Scheme 1).

The quantitative analysis of Bovenberg and Ter Rele of the Netherlands Bureau for Economic Policy Analysis (CPB) confirms that retained earnings become a less attractive source of finance than debt. Bovenberg and Ter Rele compute the cost of capital for marginal investments under both the current and the new regime. Their calculations assume an inflation rate of $2 \%$ and a real rate of interest that is exogenously fixed at $4 \%$ by international capital markets. Table 1 lists the costs of capital (under the current and the new regime) for three types of investors: individual investors facing average marginal tax rates, individual investors facing the top marginal tax rate, and institutional investors which do not pay any personal capital income taxes. Investors are assumed to arbitrage between the various investments so that each investor earns the same after-tax yield on all investments. 


\section{[Table 1]}

Table 1 shows that the tax reform leaves the cost of debt finance more or less unaffected. This cost rises slightly for proprietorships and owner-occupied housing because the reduction of the top marginal income tax rates reduces the value of interest deductions. The required return on retained earnings increases substantially for shareholders subject to the personal income tax. Under the current tax system, the cost of debt finance exceeds the cost of retained earnings for corporations that are financed by investors facing high marginal tax rates. Under the new income tax, in contrast, the required return on retained earnings exceeds that on debt for all types of Dutch investors, including investors facing high marginal tax rates. The documented larger gap between the cost of retained earnings and debt finance encourages corporations that rely on Dutch investors for their equity capital to increase their debt finance. The shareholdings of corporations that rely also on non-residents and taxexempt institutions for their equity needs will shift away from Dutch individual investors.

The new tax system also raises he costs of equity finance in owner-occupied housing and proprietorships (see Table 1), for two reasons. Firstly, the abolition of the current system of personal wealth taxation, which includes tax preferences for business equity and owner-occupied housing, differentially raises equity costs. Secondly, owneroccupied housing and the business equity of proprietors are taxed in box 1, but alternative financial investments are taxed in box 3. Hence, the costs of debt and equity are no longer treated symmetrically: the nominal interest costs of debt remain deductible at progressive rates in box 1 , whereas the alternative investment of equity capital in the capital market is taxed at a proportional rate of only $30 \%$ on a presumptive return of only $4 \%$. As is the case for corporate investments, the higher costs of equity finance will result in the substitution of debt for equity finance. Especially households subject to high marginal tax rates in box 1 face a substantial tax incentive to finance their own homes and businesses with debt and to invest their own equity in assets assigned to box 3 .

\section{Retained profits versus new shares}

Under the current regime, financing through retained profits is more advantageous than financing through issuing new shares (see Table 1). After all, the cost of profit retention (i.e., the net dividend that shareholders forego) is lower than the cost of new equity. The presumptive capital income tax, in contrast, does not depend on the form in which the return on equity is enjoyed (dividend or capital gain). As a direct consequence, the decision to distribute profits is no longer being distorted and issuing new shares is no longer less attractive (apart from transaction costs) than retaining profits. $^{8}$ This should shift equity capital from mature companies (insiders), which generate retained profits, to new rapidly growing companies (outsiders), which have to rely on the external capital market to attract equity. In this way, the new tax regime should promote a more efficient allocation of capital and facilitate the entry of new firms.

\footnotetext{
${ }^{8}$ Table 1 shows that new shares still suffer from a slight tax disadvantage compared to retained earnings. This is due to a separate low-rate tax on newly paid-in capital.
} 


\section{Business form}

The tax reform heralds the further demise of the closely-held company. Prior to 1997, this business form was greatly favored, because current profits were taxed at the corporation tax rate of $35 \%$, while (deferred) profit distributions and realized capital gains on dominant holdings attracted $20 \%$ tax, instead of the progressive income tax rates up to $60 \%$ levied on other income. Director-shareholders, moreover, could transform their labor income into capital income without any limit. In 1997, a fictitious wage was imputed to director-shareholders and the tax rate on distributions and capital gains was raised to $25 \%$. Under the new income tax, the gap vis-à-vis the proprietorship form is narrowed further. Although the self-employed are subject to higher personal income tax rates (up to 52\%), they benefit from being able to deduct interest on debt applied in the business at those rates and from the relatively lower presumptive tax rate (in box 3) on financial investments outside their own businesses. Beyond that, the new tax regime introduces various anti-avoidance provisions under which the income from debt capital and real estate that dominant shareholders put at the disposal of closely-held companies is taxed at progressive rates in box 1 (see Scheme 1).

\section{c. Enforcement}

Under the presumptive capital income tax, the arbitrage opportunities between various income items taxed at varying rates are confined to five boxes (see Scheme 1). Under the current tax regime, investors face a tax incentive to borrow (and deduct the interest expense at high marginal rates) and invest the funds in financial products that generate their returns mainly in the form of capital gains, which escape the personal income tax. Under the new tax regime, in contrast, the tax incentive to borrow vanishes in box 3, because the presumptive capital income tax does not make a distinction between interest, dividends, and capital gains. However, the progressive tax rate structure is maintained in box 1. Moreover, different proportional tax rates apply in boxes 2 and 4, the income tax on pension savings in box 5 can be deferred, and the return on debt remains exempt from corporation tax. Thus, an incentive remains to relabel highly taxed income items into items subject to lower tax rates.

For individuals earning high labor incomes, it becomes more attractive under the new regime to finance the purchase of their home by debt. In the event, these individuals benefit fully from the deduction of the nominal mortgage interest against the top marginal rate of the personal income tax in box 1, while they are able to invest their own equity against the $30 \%$ rate on a relatively low presumptive return in box 3 . This form of tax arbitrage erodes the tax base in box 1, undermines the effective progressivity of the income tax, and distorts the allocation of capital and risk.

The increased attraction of debt finance for companies (especially compared to retained profits) erodes the base of the corporation tax. Dominant shareholders face a tax incentive to transfer equity from the business level to the personal level. In this way, income is shifted from box 4 and box 2 to box 3. Other arbitrage opportunities can also be foreseen, such as the transformation of progressively taxed labor income into lower taxed capital income and the manipulation of assets around the dates at which the presumptive income tax ascertains the value of taxable assets (twice a year). The weak spots of the current tax regime are well known. Taxpayers and the legislator still have to discover the loopholes of the new regime. No doubt, taxpayers 
will uncover tax avoidance strategies, which neither the tax authorities nor we anticipate yet.

\section{d. Towards a comprehensive presumptive capital income tax?}

By excluding owner-occupied housing, equity in closely-held companies and proprietorships and pension wealth, the presumptive capital income tax features a relatively small base. Accordingly, tax fences continue to be necessary between the various boxes in order to limit the opportunities for tax arbitrage. These tax fences substantially complicate the new tax, as indicated above. Broadening the base of the presumptive tax would reduce the need for tax fences. In particular, the rental value of owner-occupied property could gradually be increased from the current return of $1.25 \%$ of the value of the property to a presumptive return of $4 \%$. At that point, owner-occupied housing could be moved from box 1 to box 3 . The inclusion of the business equity of proprietors and the equity capital (as well as selected assets now in box 1) of dominant shareholders in closely-held companies in the tax base would further broaden the presumptive capital income tax. In addition, pension savings could gradually (and possibly partly) become subject to the presumptive capital income tax. These changes would transform the presumptive capital income tax into a comprehensive net wealth tax and confine the base of the personal income tax to labor income.

\section{Capital gains tax}

If actual capital income would be taxed comprehensively, interest, dividend and rental income would have to be included in the base (as is the case under the current regime). Beyond that, capital gains would have to be taxed. In the Netherlands, capital gains tax is already being levied on the sale of a dominant holding in a closely-held company and on business assets. Capital gains are not taxed, however, when personally held assets, such as securities and real estate, are sold. In designing the tax reform, the Dutch cabinet rejected a capital gains tax on these assets for the following reasons: asset holders would defer the realization of capital gains thereby distorting ownership and risk patterns, risk taking would be harmed, correcting the taxable return for inflation would be difficult, and fairness required that tax be levied when liquid funds would be available. These arguments are evaluated on the basis of the existing literature. ${ }^{9}$

\section{a. Deferral and lock-in}

The main objection against a capital gains tax based on the realization principle is that the tax is largely elective. Indeed, the effective tax rate on capital gains declines with the holding period of an asset. Deferral implies that the taxpayer can reinvest the deferred capital gain against the current (compounded) tax-free rate of return. In fact the return on the capital gain attributable to the deferral goes untaxed. To illustrate, if the nominal rate of a capital gains tax is $30 \%$ and the interest rate (before tax) is $6 \%$, then the effective tax rate on one euro of tax which does not have to be paid now but

\footnotetext{
${ }^{9}$ For one of the latest contributions, see Burman (1999). For the economic effects of a capital gains tax, see also Auerbach (1988) and Auten and Cordes (1991)). For an early review of the literature on capital gains taxation, see Hoerner (1992).
} 
after 3 years becomes $25.2 \%\left[0.03 /(1+0.06)^{3}\right]$. This effective tax rate can be viewed as the weighted average of the rate of $30 \%$ on the original capital gain and a rate of $0 \%$ on the additional return that accrues on account of deferral.

Differences in the scope for tax deferral imply that capital gains are taxed at varying rates. This violates the ability-to-pay criterion. Furthermore, investors are encouraged to hold on to assets carrying substantial accrued capital gains, because the additional returns on investing these capital gains are in fact tax exempt. This so-called lock-in effect interferes with the efficient functioning of the capital market and distorts ownership patterns. Lock-in can also destabilize the stock market, because shares are sold when prices decline (to realize losses) and held onto when prices rise (to defer gains realization). Beyond that, taxing capital gains on a realization basis invites tax arbitrage. Investments on which capital gains can be deferred can be financed by loans of which the interest is immediately deductible. These tax induced transactions, which permit investors to have their cake and eat it too, erode the tax base. These issues are especially relevant for financial products sold in innovative capital markets, because modern financial markets allow investors to defer gains without having to assume additional risk.

\section{b. Risk taking behavior}

In rejecting a capital gains tax, the Dutch cabinet argued that countries levying capital gains taxes are increasingly being confronted with the harmful effects of such taxes on risk taking behavior. However, if capital losses are fully deductible, a capital gains tax should encourage rather than discourage risk taking. After all, loss taking (and the attendant tax relief) can be accelerated, whereas profits (and the attendant tax liabilities) can be deferred. Risky investments should thus become more attractive. ${ }^{10}$ This subsidy to risk taking behavior, however, erodes the tax base. To prevent this, the tax authorities might want to put limitations on the deduction of losses from other taxable income. Such limits on loss taking discourage risk-taking behavior. The government thus faces a trade-off between protecting the tax base and encouraging risk taking.

\section{c. Correcting for inflation}

The Dutch cabinet pointed also to the need for a complex inflation correction. This argument, however, applies not only to capital gains but also to other forms of capital income. In principle, all capital income and expense items should be corrected for inflation. If only capital gains would be corrected for inflation, investors would be encouraged to buy assets yielding capital gains and to finance these purchases by loans (of which the inflation component of the nominal interest would be fully deductible). The asymmetric treatment of investments and loans thus erodes the tax base, distorts capital allocation, and invites tax arbitrage. Inflation corrections require complicated legislative provisions. At low inflation rates, therefore, most countries do not correct taxable capital income for inflation. The application of a moderate tax rate can mitigate the potentially harmful effects.

\footnotetext{
${ }^{10}$ Even without the asymmetric realization of gains and losses, a capital gains tax could stimulate risk taking compared to the presumptive income tax (i.e., a wealth tax). This would be the case if the government, which shares the risks of investors under an ex-post income tax, could better pool risks than the capital market (see Atkinson and Stiglitz, 1980, at 118).
} 


\section{d. Liquidity concerns}

The realization rules is based on the notion that tax payments can be demanded only if liquid funds are available. ${ }^{11}$ In modern financial markets, however, this rule is increasingly at odds with the ability-to-pay criterion: realization is a matter of portfolio management rather than income definition. Securities, especially if traded on the stock exchange, are as liquid as a bank deposit. In any case, other income items, such as the rental value of owner-occupied property, are also taxed in the Netherlands without liquid funds necessarily being available. The same holds true for ex-ante taxes, such as the current net wealth tax and the newly proposed presumptive capital income tax.

In summary, the realization rule has made the capital gains tax largely elective, while anti-deferral provisions have greatly complicated the application of the tax. Even these provisions have no teeth if capital gains can be passed on untaxed at death by assuming that the heirs acquire the capital assets of the deceased at market value. ${ }^{12}$ In the Netherlands, proprietors and dominant shareholders of closely-held companies have to pay tax on accrued capital gains at the time of death. In a similar fashion, if a comprehensive capital gains tax were adopted, individual taxpayers should incur tax on their capital gains at the time of death.

\section{Retrospective capital gains taxation}

The tax literature has developed various methods to eliminate the incentive to defer realization (and hence the lock-in effect) by charging interest on the deferred tax at the time of realization. Under the Auerbach (1991) method, when an asset is disposed of, the value at sale is deemed to have resulted from appreciation at the risk-free interest rate from the date of purchase. Tax is due on this deferred interest with additional interest thereon to compensate for the value of deferral. Under the Auerbach method, the investor-specific risk premium escapes the tax. ${ }^{13}$ Information requirements are minimal. Since the tax owed on the asset is independent of the purchase price, only the sale price and the length of the holding period have to be observed.

While the Auerbach method solves the efficiency (lock-in) issue, ability-to-pay (measured by income) is not fully satisfied because the investor-specific risk premium goes untaxed. The Bradford (1995) method, in contrast, does tax this risk premium. Bradford requires the taxpayer to set a Gain Reference Date (GRD) and a Gain Tax Rate (GRT) at the time of the investment. As under the Auerbach method, taxable income is computed at the time of realization by assuming that the capital asset has increased in value at the risk-free interest rate from the GRD. Furthermore, the purchase price is presumed to have increased in value at the risk-free rate until the

\footnotetext{
${ }^{11}$ This rule also plays an important role in determining taxable profits. Indeed, the realization principle is closely associated with sound accounting principles.

${ }^{12}$ This is the rule in the United States where some $50 \%$ of the potential base of the capital gains tax leaks away because the 'angel of death' pays a visit. See Gravelle (1995).

${ }^{13}$ Auerbach (1991) notes that his approach captures the capital gain attributable to the capitalized idea of the investor but fails to capture the initial income associated with the idea. He suggests that special rules would be necessary in "such special and easily identifiable cases."
} 
GRD. Tax is charged on both presumed increases with interest on the deferred tax. In contrast to the Auerbach method, the Bradford method charges tax at the GRT on the investor-risk premium, which is presumed to have been capitalized at the GRD. Interest is also charged on this capital gain. Obviously, the information requirements under the Bradford method are substantially greater than under the Auerbach method: in addition, values at the time of purchase and the GRD have to be observed, as well as the GRD and the GRT themselves.

Retrospective capital gains taxation also brings problems in its train. While it eliminates time-shifting tax planning, it creates an incentive for entity-shifting tax planning, whereby taxpayers shift income across assets. That incentive arises under a retrospective capital gains tax because effective tax rates on excess returns vary across assets. $^{14}$ Nevertheless, the general idea of maintaining the realization principle with interest on the deferred tax seems worthy of consideration if taxation at the time of accretion is problematic on account of valuation and cash-flow problems for particular assets, such as real estate and small businesses.

\section{Capital accretion tax}

According to the S-H-S income concept, the annual accretion of wealth is the most ideal base for taxing capital income. ${ }^{15}$ Effective tax rates coincide with statutory rates and lock-in effects are eliminated. The tax liability is settled annually so that no large potential capital gains tax liabilities are carried forward that have to be paid at some future date. Tax avoidance is thus more difficult and less rewarding. As a direct consequence, administrative and compliance costs are lower.

In the United States, the desirability and feasibility of a capital accretion tax, or markto-market $\operatorname{tax}$ as the tax is called, receives increasing attention in the scholarly literature. ${ }^{16}$ Most analysts agree, however, that political and administrative obstacles lie in the way of taxing illiquid assets, such as real estate (especially owner-occupied housing) and business assets, on an accretion basis. The discussion therefore focuses on delimitating these illiquid capital assets (which should continue to be subject to the prevailing capital gains tax) from the assets that should fall under the mark-to-market tax, on valuation issues, and on the relationship between the tax rate of the mark-tomarket tax and the realization-based capital gains tax.

On delimitation, agreement appears to be emerging that securities, such as stocks, bonds, derivatives and debt claims, can be included in the base of the mark-to-market tax, while real estate and small businesses should be subject to a conventional capital gains tax. As regards the valuation of specified securities, the Financial Accounting Standards Board (FASB) in the United States believes that derivatives do not present insurmountable problems. Indeed, companies are already obliged to publish the market value of all their financial instruments. As regards tax rates, Weisbach (2000)

\footnotetext{
${ }^{14}$ This issue is alluded to by Auerbach (1991). For a general treatment, see also Knoll (1998).

${ }^{15}$ In the United States, this approach is already applied to specific derivatives, such as options, futures, forwards, and swaps.

${ }^{16}$ For a pioneering article, see Shakov (1986), and for a general treatment, also Halperin (1997). The discussion in this section draws on Weisbach (2000) who favors a mixed accretion/capital gains tax system. For an interesting view, see also Schenk (2000) who favors a presumptive income tax.
} 
points out that the average effective tax rate on capital gains should closely approximate the capital accretion tax rate. This could be achieved by charging interest on the capital gains tax under the assumption that the gain has accrued over the holding period in line with, say, the average price index for the hard-to-value asset, such as real estate.

Special attention should be given to the interaction of the capital accretion tax and the corporation tax. In principle, the corporation tax would become redundant, because distributed and retained profits would already be taxed under the capital accretion tax. The incentive to retain profits would be eliminated. If the corporation tax would be retained and interest remained deductible in ascertaining taxable profits, equity would be discriminated against compared with debt. The corporation tax, however, could be reformed to function as a withholding tax for the capital accretion tax - whereby the tax on the return on equity as well as debt would be levied at source.

\section{Evaluation and preferred alternative}

\section{a. Comparative analysis}

The Dutch Government has decided to abolish the tax on actual personal capital income and to introduce a partial net wealth tax. The new net wealth tax on savings deposits, securities and real estate is called a presumptive capital income tax. The tax rate of $1.2 \%$ on the value of these assets (net of liabilities) is computed as the product of a presumptive return of $4 \%$ and a proportional tax rate of $30 \%$. At the same time, the existing net wealth tax is abolished, but the present tax on business profits - levied on the basis of actual returns, including capital gains - is maintained. This applies also to capital gains of shareholders owning a dominant holding in a closely-held company.

A fundamental objection to the presumptive capital income tax is that it violates ability-to-pay measured in terms of income. The individual-specific investment premium (which can be associated especially with wealthy investors) escapes tax, while the government does not share in the good and bad luck of investors. Also, a capital gains tax based on the realization principle does not fully satisfy this ability-topay criterion. After all, capital income earners are taxed at varying rates depending on the extent to which they are able to defer the realization of their capital gains. Only the capital accretion tax appears to meet the ability-to-pay criterion measured in terms of income.

All approaches suffer from practical shortcomings. In particular, the presumptive capital income tax proposed by the Dutch Government worsens the discrimination of equity vis-à-vis debt. Furthermore, the small tax base distorts economic choices, encourages tax arbitrage, and harms revenue. Broadening the tax base would alleviate these problems. The presumptive capital income tax would then become akin to a comprehensive net wealth tax. Moreover, the asymmetry between the taxation of actual returns at the business level and presumptive returns at the individual level complicates coordination between the two levels. Last but not least, the presumptive capital income tax harms efforts to coordinate capital income taxes within the European Union. Whereas the Netherlands is resorting to ex-ante taxes on a 
presumptive return, other member states are strengthening ex-post taxes on capital income, including capital gains taxes and withholding taxes.

The major drawback of a conventional capital gains tax is that taxpayers are encouraged to defer the realization of capital gains and to accelerate the realization of capital losses. Complicated anti-avoidance provisions are often introduced to forestall this tax-driven behavior. This shortcoming can be mitigated, but not eliminated, by deeming realization to occur at death and by charging interest on the deferred tax. This points in the direction of a capital accretion tax. Generally, the problem with a capital accretion tax is that it is difficult to apply to real estate (including owneroccupied housing) and small businesses due to serious valuation problems. For these assets, a capital gains tax regime (preferably with a rough-and-ready interest charge on deferred taxes) would have to be maintained.

The valuation problems are smallest under a capital gains tax as long as no effort is made to charge interest on the deferred tax that correctly reflects the built-up of the gains over the holding period. In that case, the market generates the required information when the asset changes hands. For liquid financial products, financial markets provide the information needed by a presumptive capital income tax (net wealth tax), a capital gains tax that attempts to charge interest as gains accrue, and a capital accretion tax. Illiquid assets, however, have to be valued on a discretionary basis under these taxes. Interestingly, the Dutch presumptive capital income tax includes hard-to-value personal real estate in its base, including owner-occupied housing (albeit taxed in box 1 instead of box 3). This implies that the Dutch Government believes that real estate, as well as liquid financial products, can be valued annually for tax purposes. Moreover, under the current net wealth tax, also small businesses have to be valued.

Under all alternatives, the position of the corporation tax is important. If the corporation tax would be retained (after all, it also serves as a tax on equity income of non-residents), the double taxation of distributed profits could be eliminated through an imputation system or by exempting dividend income at the individual level (if the rate of the income tax equals the tax rate of the corporation tax). Permitting shareholders to write up bases of shares with retained profits can prevent double taxation of retained profits. Under a capital accretion tax, differentiating the tax rate between equity and debt can prevent the double taxation of distributed profits. ${ }^{17}$

\section{b. Preferred choice}

As the comparative evaluation clearly indicates, trade-offs have to be made between equity, efficiency, and feasibility in choosing between the various approaches to the taxation of capital income. On the basis of the arguments presented in this paper, we conclude that if income is chosen as the best measure of ability-to-pay, then the effective and neutral taxation of capital income can best be ensured through a combination of taxes at the business level and the individual level. At the business level, these taxes should include the corporation tax and a withholding tax on interest. Such taxes ensure that residents and non-residents pay the same tax on the return of an investment. At the individual level, a combination of the approaches discussed in

\footnotetext{
${ }^{17}$ In considering these measures, one should keep in mind that double taxation does not harm incentives of mature firms if the corporation tax is confined to above-normal returns or if the tax on future profit distributions is capitalized in lower share values.
} 
this paper would be our preferred choice: (1) a capital accretion tax to tax the returns on financial products, (2) a capital gains tax to tax the returns on real estate (with interest on the deferred tax to reduce lock-in), and (3) a broad presumptive capital income tax, i.e., a net wealth tax, to account for the utility of holding wealth (and to tax residents differentially higher than non-residents).

We favor a single uniform tax rate on all capital income. This would minimize deadweight losses arising from the non-neutral taxation of capital income (Auerbach, 1989). A flat rate (without a basic exemption), moreover, reduces administrative and compliance costs, because capital income arising at the company level does not have to be attributed to individuals. If revenue needs dictate a higher tax rate on labor income, we favor the separation of actual capital income (taxable at a moderate flat rate) from labor income (taxable at higher rates). This would result in a dual income tax supplemented by a net wealth tax, as found in Finland and Norway (Sørensen, 1994; Cnossen, 2000).

An effective tax on capital income requires international coordination. This applies especially to withholding taxes on interest (the return on equity is already being taxed by the corporation tax). As long as international cooperation is not forthcoming, the tax on capital income should be designed in such a way that it (a) can be optimally attuned to international developments, including intensifying international capital mobility and international tax competition, and (b) is closely in step with the tax systems in other countries in order to facilitate international coordination. Again, this appears to call for a proportional tax rate on the return of mobile capital that is not captive to the tax rate on less mobile labor.

\section{References}

Atkinson, A.B. and J.E. Stiglitz (1980). Lectures on Public Economics, New York, McGraw-Hill.

Auerbach, A.J. (1988). Capital Gains Taxation in the United States: Realization, Revenue, and Rhetoric, Brookings Papers on Economic Activity, pp. 595-631.

Auerbach, A.J. (1989). The Deadweight Loss from 'Non-neutral' Capital Income Taxation, Journal of Public Economics 40, pp. 1-36.

Auerbach, A.J. (1991). Retrospective Capital Gains Taxation, The American Economic Review 81, pp. 167-178.

Auten, G.E. and J.J. Cordes (1991). Policy Watch: Cutting Capital Gains Taxes, Journal of Economic Perspectives 5, pp. 181-192.

Bovenberg, A.L. and H.T.M. ter Rele (1998). Reforming Dutch Capital Taxation: An Analysis of Incentives to Save and Invest, CPB Research Memorandum 142, The Hague.

Bradford, D.F. (1995). Fixing Realization Accounting: Symmetry, Consistency and Correctness in the Taxation of Financial Instruments, New York University Tax Law Review 50, pp. 731-784.

Burman, L.E. (1999). The Labyrinth of Capital Gains Tax Policy, Washington DC, The Brookings Institution. 
Cnossen, S. (2000). Taxing Capital Income in the Nordic Countries: A Model for the European Union? Ch. 8 in S. Cnossen (ed.), Taxing Capital Income in the European Union: Issues and Options for Reform, Oxford University Press.

Goode, R. (1975). The Individual Income Tax, rev. ed., Washington DC, Brookings.

Gravelle, J. (1995). Capital Gains Tax Issues and Proposals: An Overview, Report 95-64S, Washington DC, Congressional Research Service.

Halperin, D. (1997). Saving the Income Tax: An Agenda for Research, Tax Notes, November 24, pp. 967-977.

Hoerner, J.A. (1992). The Capital Gains Controversy: A Tax Analysts Reader, Arlington, Virginia.

Knoll, M.S. (1998). Tax Planning, Effective Tax Rates and the Structure of the Income Tax, Draft Paper.

Schenk, D. (2000). Saving the Income Tax with a Wealth Tax, New York University Tax Law Review, forthcoming.

Shakov, D.J. (1986). Taxation without Realization: A Proposal for Accrual Taxation, University of Pennsylvania Law Review 135, pp. 1111-1186.

Simons, H.C. (1938). Personal Income Taxation: The Definition of Income as a Problem of Fiscal Policy, Chicago University Press.

Sqrensen, P.B. (1994). From the Global Income Tax to the Dual Income Tax: Recent Tax Reforms in the Nordic Countries, International Tax and Public Finance 1, pp. 57-79.

Weisbach, D.A. (2000). A Partial Mark-to Market Tax System, New York University Tax Law Review, forthcoming. 


\section{Scheme 1: Tax Reform in The Netherlands}

\section{Box / tax rate}

Box 1 (natural persons)

- $32,9 \%, 36,85 \%, 42 \%, 52 \%$

- General tax credit of euro 1,507

- Earned income tax credit of euro 803

- Other tax credits for children, single parents, and elderly

Box 2 (closely-held companies)

- $35 \%^{2}$

- $35 \%-51.25 \%^{3}$
- Wages, salaries

- Labor income of selfemployed

- Presumptive wage income of director-shareholder of closely-held company

- Pensions, social security benefits

- Other labor income

- Labor income of directorshareholder in excess of presumptive wage inome ${ }^{3}$

\section{Capital income}

- Return on capital of self-employed

- Presumptive rental value of owneroccupied housing

- Interest, rental income and capital gains on assets put at the disposal of closely-held companies by dominant shareholders ${ }^{1}$

- $\quad$ Retained profits ${ }^{3}$

- Distributed profits and capital gains on shares which form a dominant holding

Box 3 (personal wealth) ${ }^{5}$

- $30 \%$

- Lower than $30 \%$

- Higher than $30 \%$

- $35 \%$ and higher

Box 4 (corporations)

- $35 \%^{1}$

Box 5 (nontaxable entities)

- Exempt
- $\quad$ Retained profits

- $4 \%$ presumptive return on the value of savings deposits, bonds, immovable property

- Actual return higher than $4 \%$

- Actual return lower than $4 \%$

- Return on shares

- Capital income of pension funds

- Interest paid to non-residents

1 A shareholder is deemed to be a dominant shareholder if ( $\mathrm{s}$ )he (and associated persons) holds at least $5 \%$ of the shares of a (closely-held) company.

2 Profits up to euro 22,686 are taxed at $30 \%$.

3 This labor or capital income is taxed also as corporate profits in box 4.

4 The nominal tax rate is $25 \%$, but due to cumulation with the corporation tax rate of $35 \%$, the effective tax rate will be higher depending on the time at which profits are distributed. The effective tax rate on profits distributed out of current profits is 51,25\% [(35\% + 25\%(100-35)].

5 Effective tax rates are lower on account of a basic wealth exemption of euro 17,000 (euro 34,000 for couples). 
Table 1. Real Capital Costs of Marginal Investments before/after Tax Reform ${ }^{1}$

\section{Types of investors}

Average marginal tax rates $^{3}$

Corporations

-ordinary shareholders

$2.9 / 5.9$

of which

New

shares

Debt

-dominant shareholders

$3.1 / 5.5$

$6.1 / 6.1$

$2.6 / 5.9$

3.0/3.0

Proprietorships

$2.2 / 4.5$

$3.9 / 6.8$

$3.0 / 5.3$

$2.9 / 2.9$

Owner-occupied housing

$2.3 / 3.8$

$2.2 / 2.5$

$2.0 / 2.4$

High marginal tax rates ${ }^{4}$

Corporations

-ordinary shareholders

$1.6 / 5.9$

$6.1 / 6.1$

$1.1 / 5.9$

3.0/3.0

$1.0 / 5.2$

$1.3 / 6.5$

$0.9 / 5.0$

$2.9 / 2.9$

Proprietorships

$0.6 / 5.0$

Owner-occupied housing

$1.2 / 3.8$

$-$

$1.4 / 1.8$

$1.2 / 1.8$

Institutional investors

Company with ordinary

$5.9 / 5.9$

$6.1 / 6.1$

$5.9 / 5.9$

$3.0 / 3.0$

shareholders

Source: Bovenberg and Ter Rele (1998).

\footnotetext{
${ }^{1}$ On the basis of a nominal interest rate of $6 \%$ and an inflation rate of $2 \%$. Accordingly, without taxation, the real cost of capital would be $4 \%$.

${ }^{2}$ Equity financed investments of companies are assumed to consist of $10 \%$ newly issued shares and $90 \%$ retained profits.

${ }^{3}$ To compute the return after tax of equity financed investments, $10 \%$ of the wealth of households is assumed to fall under the exemption of euro 10,000 (euro 20,000 for couples) of the presumptive capital income tax. The average marginal tax rate of the income tax in box 1 is $41 \%$.

4 The top marginal income tax rates are $60 \%$ before the reform and $52 \%$ (in box 1) after the reform. Personal wealth is assumed to exceed the exemption under the presumptive capital income tax.
} 